\title{
The relation between employment hope and emotional expression levels of music teacher candidates
}

\author{
Mürvet Nevra Küpana ${ }^{1}$
}

\begin{abstract}
The objective of this research is to present the relation between employment hope levels and emotional expressivity levels of music teacher candidates. A total of 226 music teacher candidates studying Music Education in Faculties of Fine Arts in Marmara University, Trakya University, Karadeniz Technical University and Necmettin Erbakan University in 2015-2016 academic year constituted the study group of the research. Employment Hope Scale, Berkeley Expressivity Scale and Personal Information Form were used as data collection tool. Data acquired through these scales were analyzed through Pearson's Product Moment Correlation Coefficient. In this study, a significantly relation was found between employment hope levels and emotional expressivity levels of music teacher candidates.
\end{abstract}

Keywords: Hope; employment hope; emotion; emotional expressivity; music; music education.

\section{Introduction}

Hope is seen as one of the factors which may affect the fulfilling of career development tasks of an individual and career related behavior and experiences. In recent years, it is emphasized that hope, especially the needs for career accordance in career environments with dynamic and uncertain conditions, psychological strength, hope and optimistic attitudes are demanded a lot (Kepir-Savoly, 2016). Hope is the expectation for the realization of a dream imagined for something considered to happen or the realization of a certain success aimed in life. Hope is the basic impulse giving meaning to the things an individual does and making his/her actions and strive constant (Navaro, 2014).

Ability to plan the ways to be followed to reach the targets aimed despite the obstacles and the motivation or attempt for using these ways are the two main constituents of hope. The combination of these two constituents is hope (Carr, 2016). The first component of hope is setting a target. Reachability of these targets, their openness to changes and their realization containing some degree of uncertainty are important factors. Hopeful targets can be grouped under four types; a. Those aiming the desired result, b. Those preventing negative results, c. Those aiming to maintain the present condition, d. Those aiming to make the present condition better (KorkutOwen, 2016).

Employment hope has a two-dimensional structure: Psychological empowerment and goaloriented pathway. Psychological empowerment represents the confidence of an individual in his/her abilities within the context of self-respect and self-sufficiency. Goal-oriented pathway means the opportunities available to reach the goal. Employment hope concept occurs when the

\footnotetext{
${ }^{1}$ Assist. Prof. Dr., Sakarya University, State Conservatory, nkupana@sakarya.edu.tr
} 
Küpana, M. N. (2018). The relation between employment hope and emotional expression levels of music teacher candidates. Journal of Human Sciences, 15(1), 451-458. doi:10.14687/jhs.v15i1.5051

self-sufficiency confidence and the ways which would help the individuals to reach their goals combine (Akin et al, 2013). Psychological empowerment dimension includes the decision of an individual for being capable of reaching his/her goals and making plans for this. Goal-oriented pathway dimension includes the confidence of the individual that $\mathrm{s} /$ he can find the desire and ways to reach these goals when s/he determines new goals based on past experiences (Kepir-Savoly, 2016).

Hope and optimism among the main constituents of positive psychology are significant determiners of satisfaction from life (Soyer and Satan, 2015). In the meta-analysis of more than hundred studies on the subject, psychological and physical wellness of unemployed individuals was detected lower than employed individuals (McKee-Ryan et al, 2005). There is also a connection between employment and happiness; while employed individuals are happier than unemployed, professionals and individuals working in qualified jobs are happier than unqualified ones (Argyle, 2001). Since career development lasts for the lifetime, hopefulness/hopelessness condition of an individual plays an important role in career decision stages (Kepir-Savoly, 2016).

Other interrelated constituents of hope are target-oriented motivation and target reaching ways (Korkut-Owen, 2016). Hope is defined as being determinative (activeness) and considering that there may be many ways to reach the targets. Activeness is the act of an individual to start and continue moving on a certain path towards a target. Thoughts on activeness motivate individuals while thoughts on ways constitute the adequacy of the individual in determining the ways to reach the target (Synder, 2002; as cited in Hefferon \& Boniwell, 2014, p.108). According to Synder's (2000) theory of hope, hope containing target-oriented behavior in any condition with a valuable target is determined with the interactions of the following factors:

- Valuation degree for the target or result

- Thoughts on possible ways to reach the target and how effective these would be in reaching the result or target

- Thoughts on how effective these would be in individual mediation and following the ways leading to individual targets.

In the study by Tarhan and Bacanlı (2016) based on the ideas of university students, it was detected that hope includes positive expectations for the future, adds value to life, it is important to determine aims which have a possibility of realization, hoping is not a passive way of expecting, effort should certainly be made to reach aims and especially that the individual should keep on this effort by thrusting him/herself especially in case of difficulty. High hope level is related to better adaptation in interpersonal relations, health and psychological adaptation (Rand \& Cheavens, 2009). Individuals with high personal characteristics are successful in building social support networks and continuing them and report a high degree of cognitive social support (Carr, 2016).

Emotions reflect the reactions showing how the individual perceives target oriented activities. Positive emotions are the product of the perception for a succeeded target while negative emotions are for an unaccomplished target. Individuals successfully following their targets under non-prevented or prevented conditions experience positive emotions and those prevented by the conditions experience negative emotions (Snyder, 2009). Positive and negative emotions are the byproduct of target-oriented hopeful or hopeless thought (Carr, 2016). Goleman (2012) defines feeling as a sense and certain thoughts, psychological and biological conditions and a series of behaviour tendency for this sense. Being able to experience, bear, symbolize and express a feeling are the characteristics of a healthy individual (Greenberg, 2015). Individuals who have emotional talent-who know and are able to manage their own feelings, to understand and effectively cope with the feelings of others have advantage in every field of life. Individuals who have well-developed emotional abilities can acquire mental habits to nourish their own productivity by leading their lives more fully and efficiently and individuals who cannot control their emotional lives have inner 
Küpana, M. N. (2018). The relation between employment hope and emotional expression levels of music teacher candidates. Journal of Human Sciences, 15(1), 451-458. doi:10.14687/jhs.v15i1.5051

battles which would undermine their talents which provide them to focus on work and think clearly (Goleman, 2012).

Emotions, thoughts and behaviours of humans are interconnected (Dökmen, 2015). Emotional expression is the statement of the emotional experiences of an individual in a clear and observable way through verbal and non-verbal methods (Kring, Smith Neale, 1994). Gross and John (2003) defined emotional expression as the behavioural changes accompanying the feeling (hand movement, facial expressions and voice). Emotion is reflected to the body first and the emotion dominates the body before the individual knows it is there. Reflection of emotions on the body is quicker than their reflection on thought. Emotions show their presence in the body before going up to conscience. Even the smallest emotional fluctuations are reflected on the facial expression (Baltaş, 2013).

The mind has a tendency for opening or widening when the individual experiences one of the basic positive emotions and the individual can think in an unusual way. The experience of positive emotions gathered through the effect of broadening has the ability to build individual sources which may be examined when needed. These include intellectual sources (problem solving, being open to learning), physical sources (cardiovascular health, coordination), social sources (ability to continue relations and build new ones) and psychological sources (psychological strength, optimism, identity, target orientation) Hefferon \& Boniwell, 2014).

\section{Purpose}

Music and emotions have common characteristics as the universal language of expressions. Music provides emotional awareness and ability to express their emotions for the individuals. Musical education is one of the most important tools for improving these emotional abilities. Individuals trained as the music educators of the future in fine arts education department music education branches can have different occupational targets in education phases and beliefs and motivation levels for these targets. The education these music educators of the future take contribute to their musical knowledge and skills. But their own emotional improvement and skills in addition to their ability to express and convey their feelings play an important role for their musical knowledge and skills. Emotions are also regarded as the product of perceptions for the targets and thoughts on hope in this direction. So this research was made in order to determine the relation between employment hope levels and emotional expression levels of music teacher candidates.

Sub-aims of the research are mentioned below:

1. Is there a significant correlation between employment hope "psychological empowerment" subdimension score and emotional expression total score for music teacher candidates?

2. Is there a significant correlation between employment hope "goal-oriented pathway" subdimension score and emotional expression total score for music teacher candidates?

3. Is there a significant correlation between emotional expression "positive expression" subdimension score and employment hope total score for music teacher candidates?

4. Is there a significant correlation between emotional expression "negative expression" subdimension score and employment hope total score for music teacher candidates?

5. Is there a significant correlation between expressivity "impulse intensity" sub-dimension score and employment hope total score for music teacher candidates?

6. Is there a significant correlation between employment hope total score and expressivity total score for music teacher candidates? 
Küpana, M. N. (2018). The relation between employment hope and emotional expression levels of music teacher candidates. Journal of Human Sciences, 15(1), 451-458. doi:10.14687/jhs.v15i1.5051

\section{Method and Material}

Correlational model was used in this research in order to determine the relation between employment hope levels and expressivity levels of music teacher candidates. Correlational model is the research model aiming to determine the presence of change and/or degree among two or more variables (Karasar, 2005). Correlations are strong tools which show us the direction of a relation (Salkind, 2015).

Sample

A total of 236 music teacher candidates educated in Marmara, Trakya, Karadeniz Technical and Necmettin Erbakan Universities Faculties of Education Fine Arts Education Department Music Education Branches in 2015-2016 education year constituted the study group of the research. These students were reached through a suitable sampling type. $65.9 \%$ of the study group were female and $34.1 \%$ were male students and $48.2 \%$ were between the ages of $18-20,38.9 \%$ between $21-23$ and $12.9 \%$ were 24 years old or older. $20.4 \%$ of the study group were 1 st grade, $31.4 \%$ were 2 nd grade, $30.1 \%$ rd grade and $18.1 \%$ were 4 th grade students. Individual instrument distribution was as follows in the study group: $32.3 \%$ violin, $18.1 \%$ flute, $11.1 \%$ guitar, $8.4 \%$ baglama, $7.5 \%$ violoncello, $6.2 \%$ oud, $5.3 \%$ viola, $4.9 \%$ vocal training, $2.7 \%$ qanun, $2.2 \%$ clarinet, $1.3 \%$ double bass.

\section{Data Collection Tools}

Personal Data Form, "Employment Hope Scale" and "Berkeley Expressivity Scale" was used for collecting research data. "Employment Hope Scale" was developed by Hong, Polanin and Pigott (2012) and was adapted to Turkish by Akın, Hamedoğlu, Kaya and Sarıçam (2013). The scale has 14 items and two sub-scales: Psychological empowerment (4 items) and goal-oriented pathway (10 items). Cronbach alpha inner consistency coefficients were found as .93 for the whole scale, .85 for psychological empowerment sub-dimension and .90 for goal-oriented pathway sub-dimension. "Berkeley Expressivity Scale" was developed by Gross and John (1995) and was adapted to Turkish by Akin (2011). The scale has 16 items and three sub-dimensions: Positive expression (4 items) and negative expression (6 items) and impulse intensity (6 items). Cronbach alpha inner consistency coefficients were found as .88 for the whole scale, .74 for positive expression sub-dimension, .82 for negative expression sub-dimension and .87 for impulse intensity sub-dimension.

\section{Data Analysis}

SPSS 20 package program was used for data evaluation. Kolmogorov-Smirnov test was used to examine normality assumption. After Kolmogorov-Smirnov Test, employment hope was calculated as $\mathrm{p}=.20$ and expressivity as $\mathrm{p}=10(\mathrm{p}>0.05)$. Kolmogorov-Smirnov normality test analysis results prove that dependent variables have a normal distribution and $\mathrm{p}$ value over 0.05 means the provision of normality (Can, 2016). So the relation between employment hope and expressivity levels of music teacher candidates was found with Pearson Product-Moment Correlation Coefficient analyses. 
Küpana, M. N. (2018). The relation between employment hope and emotional expression levels of music teacher candidates. Journal of Human Sciences, 15(1), 451-458. doi:10.14687/jhs.v15i1.5051

\section{Results}

Results of Pearson Correlation coefficient test made to determine the relation between the scores music teacher candidates took in Employment Hope Scale sub-dimensions and the total Expressivity Scale score is given in Table 1.

Table 1. Pearson Correlation Values between Employment Hope Scale Sub Dimension Scores and Expressivity Levels of Music Teacher Candidates ( $\mathrm{n}=226)$

\begin{tabular}{|c|c|c|}
\hline & & $\begin{array}{c}\text { EMOTIONAL } \\
\text { EXPRESSION } \\
\text { TOTAL }\end{array}$ \\
\hline \multirow{2}{*}{ 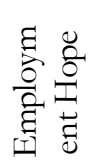 } & $\begin{array}{l}\text { Psychological } \\
\text { empowerment }\end{array}$ & $\mathrm{r}=.286^{* *}$ \\
\hline & $\begin{array}{l}\text { Goal-oriented } \\
\text { way }\end{array}$ & $\mathrm{r}=-.022$ \\
\hline
\end{tabular}

Pearson Product-Moment Correlation operation made to present whether there is a relation between employment hope sub-dimension scores and expressivity total scores of music teacher candidates shows the presence of a positive and significant level of relation between employment hope psychological strengthening sub-dimension and expressivity total score $(r=* .286, p<0.01)$. A significant relation was not found among employment hope goal-oriented pathway sub-dimension and expressivity total score $(\mathrm{r}=0.22, \mathrm{p}>.05)$. According to this result acquired, we can say that there is a significant relation between expressivity and psychological strengthening scores expressing the confidence of music teacher candidates within the context of self-esteem and self-efficacy on their abilities. But the presence of a relation cannot be mentioned between goal-oriented pathway scores expressing music teacher candidates' thrust on being able to finds ways to reach the goals and their willingness to reach the goals.

Results of Pearson Correlation coefficient test made to determine the relation between the scores music teacher candidates took in Expressivity Scale sub-dimensions and the total Employment Hope Scale score is given in Table 2.

Table 2. Pearson Correlation Values between Expressivity Scale Sub-Dimension Scores and Employment Hope Levels of Music Teacher Candidates $(n=226)$

\begin{tabular}{|c|c|c|}
\hline & & $\begin{array}{c}\text { EMPLOYMENT HOPE } \\
\text { TOTAL } \\
\end{array}$ \\
\hline \multirow{3}{*}{ 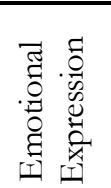 } & Positive Expression & $\mathrm{r}=.424^{* *}$ \\
\hline & Negative Expression & $\mathrm{r}=.154^{*}$ \\
\hline & Impulse Intensity & $\mathrm{r}=.253^{* *}$ \\
\hline
\end{tabular}

Pearson Product-Moment Correlation operation made to present whether there is a relation between expressivity sub-dimension scores and employment hope total scores of music teacher candidates shows the presence of a positive and significant level of relation between positive expressivity sub-dimension of expressivity and employment hope total score $(r=0.424, p<0.01)$. There is a positive and significant level of relation between the negative expressivity sub-dimension of expressivity and employment hope total score $(\mathrm{r}=0.154, \mathrm{p}<0.05)$. There is a positive and significant level of relation between the impulse intensity sub-dimension and employment hope total score $(\mathrm{r}=0.253, \mathrm{p}<0.01)$. According to this result acquired, a positive and significant relation 
Küpana, M. N. (2018). The relation between employment hope and emotional expression levels of music teacher candidates. Journal of Human Sciences, 15(1), 451-458. doi:10.14687/jhs.v15i1.5051

can be mentioned in all sub-dimensions of expressivity and employment hope levels for music teacher candidates.

Results of Pearson Correlation coefficient test done to determine the relation between employment hope levels and expressivity levels of music teacher candidates is given in Table 3.

Table 3. Correlation Coefficient of Employment Hope Total Scores and Expressivity Total Scores of Music Teacher Candidates ( $\mathrm{n}=226$ )

EMOTIONAL EXPRESSION

TOTAL SCORE

\begin{tabular}{lcc}
\hline & EMPLOYMENT HOPE & $\mathrm{r}=.355^{* *}$ \\
& TOTAL SCORE & \\
\hline$* * p<0.01$ &
\end{tabular}

A positive and significant relation was found between employment hope total scores and expressivity total scores of music teacher candidates $(r=0,355, p<0.01)$. According to this result acquired, it can be stated that expressivity levels increase with employment hope level of music teacher candidates and employment hope is related to the expressivity of the individual.

\section{Discussion}

In their study, Sar1 and Tunç (2016) examined the relation between psychological wellbeing and hope levels of university students and detected that hope levels also increased when the psychological wellbeing level of the individuals increased. Uzun Özer and Tezer (2008) examined the relation between hope level and positive-negative emotions and detected the effect of hope on positive feelings. In their study examining how psychological strength and hopelessness levels of teacher candidates effected their life satisfaction, Çelik, Sanberk and Deveci (2017) detected a positive significant relation between life satisfaction and psychological strength and a negative significant relation between life satisfaction and despair. Cote et al. (2006; ref. Kümbül Güler, 2012) reached the conclusion that the minds of the individuals who have a positive mood were more clear during job search in cognitive terms and this positively affected their job searching behaviour in the study they made on university students and they stated that positive emotions are more effective than negative emotions in job search. But it was also stated that negative emotions such as fear, anger and sadness which constitute an important mood determiner sometimes increase the motivation of the individual during job search. So it is stated that negative emotions have a doublesided role as they both decrease job searching success of the individual by negatively affecting the motivation of the individual and making job finding easier for the individuals by keeping the occupational expectation of job searchers at a low level (Crossley and Stanton, 2005, ref. Kümbül Güler, 2012). Işık, Deniz and Ulubey (2015) examined the potential relations between emotional intelligence and career decision competence expectation in their study and concluded that emotional intelligence is an important determiner for career decision competence expectation. A positive significant relation was found between all sub-dimensions of Career Decision Competence Expectation scale (Correct Self-Evaluation, Gathering Information on Occupations, Target Determining, Planning, Problem Solving) and all sub-dimension of Emotional Intelligence Characteristic scale (Subjective wellbeing, Self-control, Sensibility, Sociability) in the study. It can be stated that all these studies support the findings of the present research. 
Küpana, M. N. (2018). The relation between employment hope and emotional expression levels of music teacher candidates. Journal of Human Sciences, 15(1), 451-458. doi:10.14687/jhs.v15i1.5051

\section{Conclusion and Recommendations}

The relation between employment hope levels and expressivity levels of music teacher candidates was examined in this research. A positive and significant level of relation was found between psychological empowerment sub-dimension of employment hope and expressivity total score according to the research but no significant relation was found between goal-oriented pathway sub-dimension of employment hope and expressivity total score. A positive and significant relation was found between all sub-dimensions of expressivity and hope employment levels. A positive and significant relation was found between employment hope total scores and expressivity total scores of music teacher candidates. According to this, it can be stated that expressivity levels increase with employment hope level of music teacher candidates and employment hope is related to the expressivity of the individual.

In the study by Küpana (2017), it was stated that there was a significant difference in employment hope scores for psychological empowerment according to variables such as age, department, class and educational environment encouraging to study and employment hope scores for goal-oriented pathway had a significant difference according to variables such as department, individual instrument and educational environment encouraging to study. So covering the relation between employment hope levels and expressivity levels of music teacher candidates through different variables seems advantageous for this reason. It is recommended to examine this study considering different variables such as gender, class, age, academic success, individual instrument, musical performance, motivation and anxiety. It is recommended to investigate the subject with a wider sampling, to cover similar subjects so that other university students being educated in music and fine arts fields are also covered and to consider school type variable in this direction.

\section{References}

Akın, A., Hamedoğlu, M. A., Kaya, C.., \& Sarıçam, H. (2013). Turkish version of the Employment Hope Scale: The validity and reliability study. IIB International Refereed Academic Social Sciences Journal, 11(4), 56-68.

Akın, A. (2011). The validity and reliability of the Turkish version of the Berkeley Expressivity Scale. Procedia-Social and Behavioral Sciences, 30, 27-33.

Argyle, M. (2001). The psychology of happiness (2nd edition). London: Routledge.

Baltaş, Z. (2013). Duygusal žeka: Insanm dünyasım aydınlatan ve işine yansıyan ışık (6. basım). İstanbul: Remzi.

Carr, A. (2016). Poæitiffpsikoloji (Ü. Şendilek, Çev.). İstanbul: Kaknüs.

Cote, S., Saks, A. M. , \& Zikic, J. (2006). Trait affect and job search outcomes. Journal of Vocational Behavior, 68, 233-252.

Crossley, C.D., \& Stanton J.M. (2005). Negative affect and job search: Further examination of the reverse causation hypothesis. Journal of Vocational Behavior. 66, 549-560.

Çelik, M., Sanberk, İ., ve Deveci, F. (2017). Öğretmen Adaylarının Yaşam Doyumlarının Yordayıcısı Olarak Psikolojik Dayanıklilik ve Umutsuzluk. Elementary Education Online, 2017; 16(2): 654-662.

Goleman, D. (2012). Duygusal z̧eka: EQ neden IQ'dan daha önemlidir? (B. S. Yüksel, Çev.) (35. Basım). İstanbul: Varlık.

Gross J. J. ve John, O. P. (2003). Individual differences in two emotion regulation processes: implications for affect, relationships, and well-Being. Journal of Personality and Social Psychology, 85 (2), 348-362.

Gross J. J. ve John, O. P. (1995). Facets of emotional expressivity: Three self-report factors and their correlates. Personality and Individual Differences, 19, 555-568.

Greenberg, L. S. (2015). Duygu odakl terapi: Damı̧anlara duygu koçluğu yapmak. (S. B. Çelik, Çev.). Ankara: Nobel.

Hefferon, K., \& Boniwell, I. (2014). Poæiitifpsikoloji (T. Doğan, Çev.). Ankara: Nobel. 
Küpana, M. N. (2018). The relation between employment hope and emotional expression levels of music teacher candidates. Journal of Human Sciences, 15(1), 451-458. doi:10.14687/jhs.v15i1.5051

Hong, P. Y. P., Polanin, J. R., \& Pigott, T. D. (2012). Validation of the Employment Hope Scale: Measuring psychological self-sufficiency among low-income jobseekers. Research on Social Work Practise, 22(3), 323-332. doi: 10.1177/1049731511435952

Iş1k, E., Deniz, E., ve Ulubey, E. (2015). Kariyer karar1 yetkinlik beklentisinin yordayıcısı olarak duygusal zeka özelliği. 13. Ulusal Psikolojik Danısma ve Rehberlik Kongresi Bildiri Özeti Kitabı (s. 425-428). Mersin: Mersin Üniversitesi.

Karasar, N. (2005). Bilimsel arastrrma yöntemi (15. basım). Ankara: Nobel.

Kepir-Savoly, D. D. (2016). Umut ve kariyer olgunluğu. A. Demirli Yıldız (Ed.), Poritif psikoloji bağlamonda umut (s.287-304). Ankara: Nobel.

Kring, A. M., Smith, D. A. ve Neale J. M. (1994). Individual differences in dispositional expressiveness: Development and validation of the emotional expressivity scale. Journal of Personality and Social Psychology, 66 (5), 934-949.

Kümbül Güler, B. (2012). İş arama davranışı: Bütüncül psiko-sosyal bir yaklaşım. “İs, Gǚs” Endüstri İliskileri ve Insan Kaynakları Dergisi, 14 (2), 7-24.

Küpana, M. N. (2017). Mesleki müzik eğitimi alan öğrencilerin iş umudu düzeylerinin incelenmesi.

Sakarya University Journal of Education, 7 (2), 350-362.

McKee-Ryan, F., Song, Z., Wanberg, C. R., \& Kinicki, A. J. (2005). Psychological and physical wellbeing during unemployment. A meta-analytic study. Journal of Applied Psychology, 90, 53-76.

Salkind, N. J. (2015). İstatistikten nefret edenler için istatistik (A. Çuhadaroğlu, Çev.). Ankara: PegemAkademi.

Sar1, T. ve Tunç, E. (2016). Üniversite öğrencilerinde umudun yordayıc1sı olarak psikolojik iyi olma. The Journal of Academic Social Science Studies, 45, 291-302.

Snyder, C. R. (2002). Hope Theory: Rainbows in the Mind. Psychological Inquiry, 13 (4), 249-275.

Soyer, M. K., \& Satan, A. (2015). Genç yetişkinlerde yaşam doyumunun yordayıcısı olarak umut, dayanıklılık ve iyimserlik. 13. Ulusal Psikolojïk Danıșma ve Rebberlik Kongresi Bildiri Öreti Kitabı (s. 185-186). Mersin: Mersin Üniversitesi.

Uzun Özer, B. ve Tezer, E. (2008). Umut ve olumlu-olumsuz duygular arasındaki ilişkiler. Dokuz Eylül Üniversitesi Buca Eğitim Fakültesi Dergisi, 23, 81-86. 